\title{
EFFECT OF HEAT TREATMENTS AND SEASONS OF THE YEAR ON THE PROTECTIVE PROTEINS IN MILK OF DIFFERENT ANIMALS
}

\author{
HATTEM, H. E. \\ Dairy Chemistry Departement, Animal Production Research Institute, Dokki, Giza, Egypt. \\ drhamed2025@yahoo.com
}

(Manuscript received 16 November 2016 )

\begin{abstract}
The aim of the present work was to study the effect of heat treatments and seasons of year on immunoglobulin, lactoferrin and lysozyme contents in camel's, cow's and buffalo's milk. The milk samples were heat treated at 63, 72, and $95^{\circ} \mathrm{C}$ for $30 \mathrm{~min} ., 15 \mathrm{sec}$. and $15 \mathrm{~min}$. respectively. Camel's milk contained significantly higher amounts of immunoglobulin (IG), lactoferrin (LF) and lysozyme (LZ) than cow's and buffalo's milk. Heating milk at $63^{\circ} \mathrm{C} / 30 \mathrm{~min}$. had significant effect on lysozyme and lactoferrin. While the immunoglobulin was more affected in the three kinds of milk. The amounts of immunoglobulin of cow's and buffalo's milk were observed at $72^{\circ} \mathrm{C} / 15 \mathrm{sec}$. compared with camel's immunoglobulin. The amounts of lactoferrin were lost at $95^{\circ} \mathrm{C} / 15 \mathrm{~min}$. in all kinds of milk. However, at this level of heat treatment, the losses of lysozyme at $95^{\circ} \mathrm{C} / 15 \mathrm{~min}$. were $0.12 \pm 0.18,0.06 \pm 0.17$ and $0.02 \pm 0.14 \mathrm{ug} / \mathrm{ml}$ for camel's, cow's and buffalo's milk, respectively. When milk was heated at $95^{\circ} \mathrm{C} / 15 \mathrm{~min}$. camel's milk protective proteins were relatively more heat resistant than cow's and buffalo's milk proteins. It was found that the heat resistance for lysozyme > lactoferrin > immunoglobulin. The amounts of milk protective proteins were higher in winter for all kinds of milk, compared with summer milk.
\end{abstract}

Keywords : immunoglobulin, lactoferrin, lysozyme, milk, heat treatments

\section{INTRODUCTION}

Although protective proteins including lysozyme, lactoferrin and immunoglobulins represent only a minor fraction of milk proteins, they play an important role as first line defence due to their direct and indirect antimicrobial activity and for other important physiological and health promoting functions (Gorbenko, et al.,2007). It is suggested that colostral Igs and lysozyme would provide as one of the considerable prospects for consumers health promotion in the future (Benkerroum,2008). The immunoglobulins, are a family of proteins with a range of protective bioactivities. They are divided into several classes, the major immunoglobulin classes in mammary secretions are IgG, IgA and IgM (Mix, et al., 
2006). IgM is the class that appears initially when an organism is exposed to an antigen for the first time (primary infection). IgM has a low specificity and hence a lower potency in defeating the infection. IgA is the major immunoglobulin class found in mucosal secretions and prevents mucosal infections by agglutination of microbes, whereas IgG is the primary immunoglobulin class found in bovine colostrum and milk. Several subclasses of IgG being, with IgG1 and IgG2 are the major immunoglobulins in serum (Walter and Theil 2011). Immunoglobulins (Igs), together with lactoferrin and lysozyme form important antimicrobial system of bovine lacteal secretions. The concentration of the various bovine Igs in serum and in lacteal secretions varies according to the breed, age, health status, and stage of lactation of the animal (Benkerroum, 2008).

In literature there is contradictory information about thermo stability of antimicrobial proteins. According to Chen, et al., (2000) results immunoglobulins are thermolabile. Exposure to temperatures of $75{ }^{\circ} \mathrm{C}$ can reduce detectable isolated bovine IgG by $40 \%$ in $5 \mathrm{~min}$, and by $100 \%$ at $95^{\circ} \mathrm{C}$ for $15 \mathrm{~s}$. The explanation of it is conformational changes in the IgG molecule causes by heat exposure. Antigen-binding activity of bovine IgG also is reduced after heat treatment (Dominguez, et al., 2001). The studies suggesting that the antigen-binding region of the immunoglobulin molecule is more thermo labile than the other regions of the molecule, thermal protect ants such as sugars or glycerol can increase the stability of isolated IgG to heat treatment (Chen, et al., 2000). However, it was reported that IgG is the most thermostable and IgM is the least thermostable Lysozyme is an antimicrobial enzyme that is found in a wide variety of organisms and ranged from 0 to $3 \mathrm{mg} / \mathrm{L}$ in cow's milk to $790 \mathrm{mg} / \mathrm{L}$ in mare's milk (Farkey 2002). The enzyme is often used for lysing of peptidoglycan present in the bacterial cell walls. Gram-positive cells are quite susceptible to this hydrolysis as their cell walls have a high proportion of peptidoglycan. Gram-negative bacteria are less susceptible due to the presence of an outer membrane and a lower proportion of peptidoglycan. Lysozyme protects against bacterial infection by breaking down the carbohydrates in bacterial cell walls, killing them. Lysozyme also has fungicidal properties, protecting mucosal areas from invasion by pathogenic yeast or fungi. Lysozyme has been shown to inhibit viral replication and infection such HIV (Samaranayake, et al., 2001). In addition, the concentration of soluble lysozyme in milk varies considerably from one species to another and within the same species depending on various factors such as the breed, stage of lactation, parturition, nutrition, udder health and season of the year (Priyadarshini and Kansal 2003). Lysozyme is termostable, 75\% of lysozyme activity mantains after milk heat treatment $75^{\circ} \mathrm{C} 15$ min or $80^{\circ} \mathrm{C} 15 \mathrm{~s} \mathrm{(Farkey} \mathrm{2002).} \mathrm{On} \mathrm{the}$ 
other hand, the increased pool of antimicrobial components can be enriched further through concentration techniques, leading to production of products containing high immunoglobulin and lysozyme concentration. Such preparation may find beneficial application as in human healthcare and wellbeing by preventing infection and controlling microorganisms grow and diseases, as in a new functional food development (Mehra, et al., 2006). Through such processing, immunoglobulins and lysozyme are exposed to a number of conditions that may alter the structure and function of the proteins. Some of methods used for concentration or isolation of immunoglobulins and lysozyme include steps that involve exposing the protein to heat, acid or pressure which may affect the conformation of the protein, and ultimately the immunological activity of it. Independent on method, which is used for concentration immunoglobulin and lysozyme, thermal treatment, is obligatory step. The combination of temperature and time used in processing can affect also the structure of the proteins and involve unfolding and aggregation (Elfstrand, et al., 2002).

The research objective was to the protective proteins content, i.e. immunoglobulin, lactoferrin and lysozyme in milk obtained from camel's, cow's and buffalo's as affected by heat treatment and seasons of the year.

\section{MATERIALS AND METHODS}

Bulk samples of each type of milk were used in the present study. Samples were taken during winter and summer seasons. Camel's milk samples were obtained from the El-Alamin area around Alexandria. Cow's and buffalo's milk samples were collected from Animal Production Research Station( Sakha and Mehalet Mosa). Milk samples were defatted by using the separator. Skim milk was then divided into four equal portions, one portion was used as a control (raw), the others were heated at 65,72 and $95^{\circ} \mathrm{C}$ for $30 \mathrm{~min}, 15 \mathrm{sec}$. and $15 \mathrm{~min}$. respectively in a water bath. Samples were rapidly cooled to $40^{\circ} \mathrm{C}$, renneted and centrifuged at $3000 \mathrm{~g}$ for 20 min at $4^{\circ} \mathrm{C}$. The concentrations of IgG was determined in the separated whey by turbodimetric method (Gray et al., 1969) using pH-meter "Jenway 3520" and spectrophotometer "Jenway 6705 UV/VIS" (UK).

Lactoferrin and lysozyme contents were determined using the reversed-phase highperformance liquid chromatography (RP-HPLC) with UV-Vis detector according to Maynard, et al., (1989) From each sample of raw milk $50 \mathrm{ml}$ was taken and adjusted to $\mathrm{pH} 4.6$ with $0.1 \mathrm{~mol} / \mathrm{L} \mathrm{HCl}$, and allowed to stand at room temperature for about one hour for to precipite the caseins. The whey $(7 \mathrm{ml})$ was taken and centrifuged at 
$10,000 \mathrm{rpm}$ for $15 \mathrm{~min}$. Finally, whey solutions were filtered through paper quality filter discs (diameter: $125 \mathrm{~mm}$, density: $65 \mathrm{~g} / \mathrm{m} 2$, grade: 3 hours (Munktell, Germany)) and $0.20-\mu \mathrm{m}$ disposable sterile filters (Millipore type GSTF, USA). The supernatants were kept in refrigerator until analysis, and were injected into the chromatograph at the suitable time (in the amount of $20 \mu \mathrm{l}$ ). Protein separation was performed on liquid chromatography ProStar 210 model and UV-Vis ProStar 325 detector (Varian, USA). The measurements were carried out using the water/acetonitrile mobile phase at gradient elution and column NUCLEOSIL 300-5 C18 (Varian, USA) of $250 \mathrm{~mm}$ length and $4.6 \mathrm{~mm}$ diameter. The mobile phase was solvent A ( $90 \%$ water, $10 \%$ acetonitryle) and solvent B (90\% acetonitryle, 10\% water), purchased from Sigma (Germany). The solvents were filtered through $0.45-\mu \mathrm{m}$ filters (Millipore, USA) and degassed by using ultrasounds. The total analysis time for a single sample was $35 \mathrm{~min}$ at $205 \mathrm{~nm}$ wavelength with column temperature of $37^{\circ} \mathrm{C}$. The analyses of reference substances were conducted under the same conditions. On the grounds of the obtained chromatograms, using program Star 6.2 Chromatography Workstation (Varian, USA), the qualitative and quantitative identification of each substance were performed followed by their concentration determination. Calibration of the chromatographic system for whey proteins determination was carried out by the external standard method. For this purpose, each protein was calibrated individually by injecting solutions of the standards $(20 \mu \mathrm{l})$. The standards were purified proteins, i.e. lactoferrin (90\%) from bovine milk and lysozyme $(95 \%)$ from hen egg whites, which were purchased from Sigma (Germany). All chemicals were of HPLC analytical grade. Concentrations of lactoferrin and lysozyme solutions ranged from 0 to $200 \mathrm{mg} / \mathrm{l}$ and from 0 to $20 \mu \mathrm{g} / \mathrm{l}$ respectively, and were prepared to create the calibration curves. The limits of quantification LOQ (for lactoferrin - $40 \mathrm{mg} / \mathrm{l}$ and for lysozyme - $2.8 \mu \mathrm{g} / \mathrm{l}$ ) and detection LOD (for lactoferrin - $8.7 \mathrm{mg} / \mathrm{l}$ and lysozyme$0.9 \mu \mathrm{g} / \mathrm{l})$ were determined.

Statistical Analysis:-

The obtained data were statistically analyzed for variance average and Duncan's test according to SPSS computer program (SPSS, 1998).

\section{RESULTS AND DISCUSSION}

The mean quantity of total immunoglobulins in raw camel's milk was $1.86 \pm$ $0.11 \mathrm{mg} / \mathrm{ml}$ (Table 1 ). The decrease of immunoglobulin quantity was recorded by heat treatment at $63^{\circ} \mathrm{C} 30 \mathrm{~min}$. (Fig 1) Quantity of immunoglobulin was reduced to $1.58 \pm 0.11$. Increasing heat treatment up to $72{ }^{\circ} \mathrm{C}$ and $95^{\circ} \mathrm{C}$ with holding time of 
15sec. and $15 \mathrm{~min}$. respectively had similar influence on quantity of immunoglobulin, since it reduced to $0.52 \pm 0.12$ and $0.04 \pm 0.13 \mathrm{mg} / \mathrm{ml}$ respectively. Quantity of immunoglobulin from camel milk was the highest and more resistant to heat treatment compared to cow's and buffalo's milk. Some studies on total cow milk immunoglobulins and their heat stability indicated that heating skim milk at $70^{\circ} \mathrm{C}$ for 30 min resulted $89 \%$ loss in immunoglobulin. Li-Chan, et al., (1995) found that no change in bovine IgG after heating cow milk at $62.7^{\circ} \mathrm{C}$ for 30 min but Dhar, et al., (1996) reported that pasteurization of cow milk at $71^{\circ} \mathrm{C}$ for $9 \mathrm{~s}$ resulted retention of $75 \%$ of IgG. Vetter et al., (2013) found that HTST pasteurization $\left(72^{\circ} \mathrm{C} / 15 \mathrm{~s}\right.$ ) led to 25 to $40 \%$ loss of IgG concentration. On the other hand, quantity of immunoglobulin as affected by season was studied. The highest quantity of immunoglobulin was recorded in raw camel's milk $(2.23 \pm 0.12 \mathrm{mg} / \mathrm{ml})$ in winter season, but the lowest quantity was recorded in raw buffalo's milk in winter season $(0.36 \pm 0.16 \mathrm{mg} / \mathrm{ml})$ compared to summer season. Milk of camel's, cow's and buffalo's grazing the pasture was characterized by a higher content of IgG by $39.6 \mathrm{mg} / \mathrm{L}$ (Król, et al., (2011).

Table 1. Effect of heat treatments and seasons of the year on the quantity of Immunoglobulin $(\mathrm{mg} / \mathrm{ml})$ in camel's, cow's and buffalo's milk(Average $\pm \mathrm{SE}$ of three replicates).

\begin{tabular}{|c|c|c|c|c|c|c|}
\hline \multirow{2}{*}{ Treatments } & \multicolumn{3}{|c|}{ Summer } & \multicolumn{3}{c|}{ Winter } \\
\cline { 2 - 7 } & Camel's milk & $\begin{array}{c}\text { Cow's } \\
\text { milk }\end{array}$ & $\begin{array}{c}\text { Buffalo's } \\
\text { milk }\end{array}$ & $\begin{array}{c}\text { Camel's } \\
\text { milk }\end{array}$ & $\begin{array}{c}\text { Cow's } \\
\text { milk }\end{array}$ & $\begin{array}{c}\text { Buffalo's } \\
\text { milk }\end{array}$ \\
\hline Control & $1.86 \pm 0.11^{\mathrm{a}}$ & $0.39 \pm 0.12^{\mathrm{a}}$ & $0.28 \pm 0.14^{\mathrm{a}}$ & $2.23 \pm 0.12^{\mathrm{a}}$ & $0.52 \pm 0.15^{\mathrm{a}}$ & $0.36 \pm 0.16^{\mathrm{a}}$ \\
\hline $\begin{array}{c}63^{\circ} \mathrm{C} / 30 \\
\mathrm{~min} .\end{array}$ & $1.58 \pm 0.11^{\mathrm{b}}$ & $0.18 \pm 0.14^{\mathrm{b}}$ & $0.12 \pm 0.16^{\mathrm{b}}$ & $2.02 \pm 0.14^{\mathrm{b}}$ & $0.35 \pm 0.14^{\mathrm{b}}$ & $0.18 \pm 0.17^{\mathrm{b}}$ \\
\hline $\begin{array}{c}72^{\circ} \mathrm{C} / 15 \\
\mathrm{Sec} .\end{array}$ & $0.52 \pm 0.12^{\mathrm{c}}$ & $0.09 \pm 0.16^{\mathrm{c}}$ & $0.03 \pm 0.17^{\mathrm{c}}$ & $0.70 \pm 0.13^{\mathrm{c}}$ & $0.06 \pm 0.16^{\mathrm{c}}$ & $0.02 \pm 0.15^{\mathrm{c}}$ \\
\hline $95^{\circ} \mathrm{C} / 15 \mathrm{~min}$. & $0.04 \pm 0.13^{\mathrm{d}}$ & $\mathrm{ND}$ & $\mathrm{ND}$ & $0.05 \pm 0.14^{\mathrm{d}}$ & $\mathrm{ND}$ & $\mathrm{ND}$ \\
\hline
\end{tabular}

Means \pm standard error

$a, b, c$ Means within the same column with different letters are significantly different $(P \leq 0.05)$. ND $=$ Not detected

Raw camel's milk contained a significantly $(P \leq 0.05)$ higher level of lactoferrin compared to cow's and buffalo's milk (Table 2). The effect of heat treatments on lactoferrin content was shown in Fig. 2. Heating milk at $63^{\circ} \mathrm{C}$ for $30 \mathrm{~min}$. had significant effect on lactoferrin quantity in the milk for all species. However, increasing the temperature to $72^{\circ} \mathrm{C}$ for $15 \mathrm{sec}$. resulted signicant loss of lactoferrin. Luf and Rosner (1997) found that HTST treatment of cow milk has no significant effect on 
lactoferrin denaturation, whereas, heat treatment at $63^{\circ} \mathrm{C}$ for 30 min reduced the native lactoferrin content by $40 \%$. In the present study, heating of milk at $95^{\circ} \mathrm{C}$ for 15 min. resulted a complete loss of lactoferrin in cow's and buffalo's milk versus $96.5 \%$ of denaturation of camel lactoferrin. Generally, on the basis of these findings, it could be concluded that camel milk lactoferrin was more resistant to heat than that of cow's and buffalo's milk. On the other hand, season of the year affected the quantity of lactoferrin. The highest quantity of lactoferrin was recorded in raw camel's milk(0.72 $\pm 0.17 \mathrm{mg} / \mathrm{ml}$ ) in winter season, but the lowest one was recorded in raw buffalo's milk in winter season $(0.31 \pm 0.23 \mathrm{mg} / \mathrm{ml})$ compared to summer season. Some authors found lower levels of lactoferrin in the milk of cows kept on the pasture (145.66-148.83 mg/l) in comparison with milk of cows fed in barns (174.63-204.89 $\mathrm{mg} / \mathrm{l})$. Turner, et al., (2003) also reported higher levels of lactoferrin in milk of cows fed system in relation to milk of cows grazing the pasture.

Table 2. Effect of heat treatments and seasons of the year the on quantity of lactoferrin content $(\mathrm{mg} / \mathrm{ml})$ in camel's, cow's and buffalo's milk (Average \pm SE of three replicates).

\begin{tabular}{|c|c|c|c|c|c|c|}
\hline \multirow{2}{*}{ Treatments } & \multicolumn{5}{|c|}{ Summar } & \multicolumn{3}{c|}{ Winter } \\
\cline { 2 - 7 } & $\begin{array}{c}\text { Camel's } \\
\text { milk }\end{array}$ & $\begin{array}{c}\text { Cow's } \\
\text { milk }\end{array}$ & $\begin{array}{c}\text { Buffalo's } \\
\text { milk }\end{array}$ & $\begin{array}{c}\text { Camel's } \\
\text { milk }\end{array}$ & $\begin{array}{c}\text { Cow's } \\
\text { milk }\end{array}$ & $\begin{array}{c}\text { Buffalo's } \\
\text { milk }\end{array}$ \\
\hline Control & $0.55 \pm 0.21^{\mathrm{a}}$ & $0.38 \pm 0.19^{\mathrm{a}}$ & $0.22 \pm 0.22^{\mathrm{a}}$ & $0.72 \pm 0.17^{\mathrm{a}}$ & $0.49 \pm 0.13^{\mathrm{a}}$ & $0.31 \pm 0.23^{\mathrm{a}}$ \\
\hline $\begin{array}{c}63^{\circ} \mathrm{C} / 30 \\
\text { min. }\end{array}$ & $0.46 \pm 0.16^{\mathrm{b}}$ & $0.19 \pm 0.17^{\mathrm{b}}$ & $0.12 \pm 0.18^{\mathrm{b}}$ & $0.65 \pm 0.18^{\mathrm{b}}$ & $0.25 \pm 0.16^{\mathrm{b}}$ & $0.15 \pm 0.15^{\mathrm{b}}$ \\
\hline $72^{\circ} \mathrm{C} / 15$ & $0.11 \pm 0.18^{\mathrm{c}}$ & $0.08 \pm 0.15^{\mathrm{c}}$ & $0.08 \pm 0.16^{\mathrm{c}}$ & $0.21 \pm 0.16^{\mathrm{c}}$ & $0.12 \pm 0.19^{\mathrm{c}}$ & $0.10 \pm 0.18^{\mathrm{c}}$ \\
\hline Sec. & & & & & & \\
\hline $95^{\circ} \mathrm{C} / 15$ min. & $0.06 \pm 0.13^{\mathrm{d}}$ & $0.05 \pm 0.14^{\mathrm{d}}$ & $\mathrm{ND}$ & $0.08 \pm 0.14^{\mathrm{d}}$ & $\mathrm{ND}$ & $\mathrm{ND}$ \\
\hline
\end{tabular}

Means \pm standard error

$a, b, c$ Means within the same column with different letters are significantly different $(P \leq 0.05)$. $\mathrm{ND}=$ Not detected 

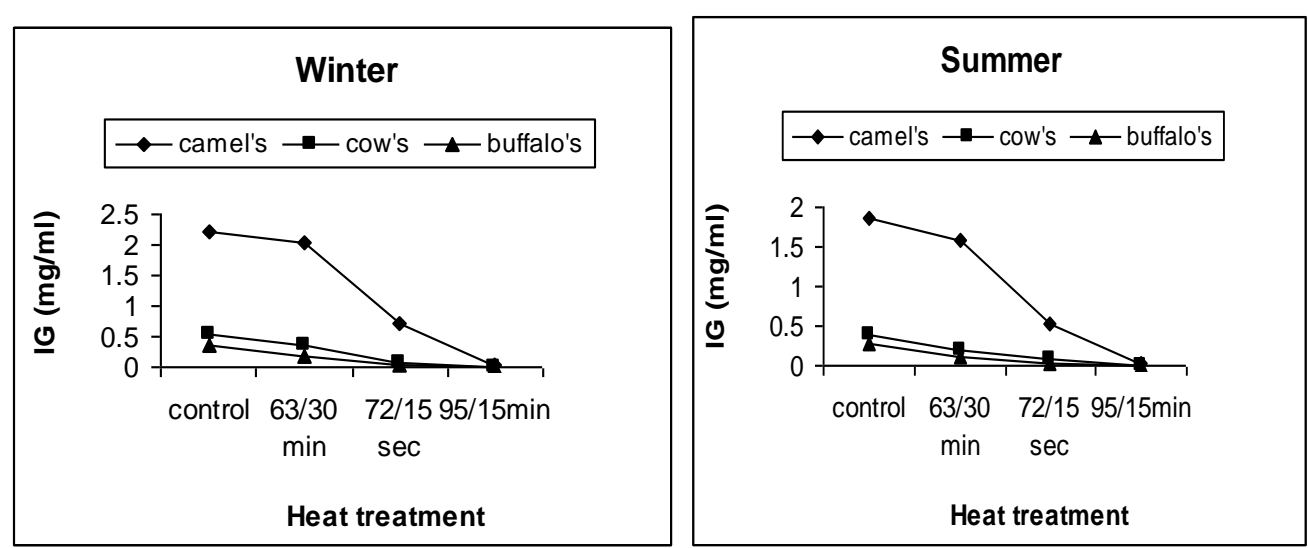

Fig. 1. Effect of heat treatment and season on camel's, cow's and buffalo's milk immunoglobulin.
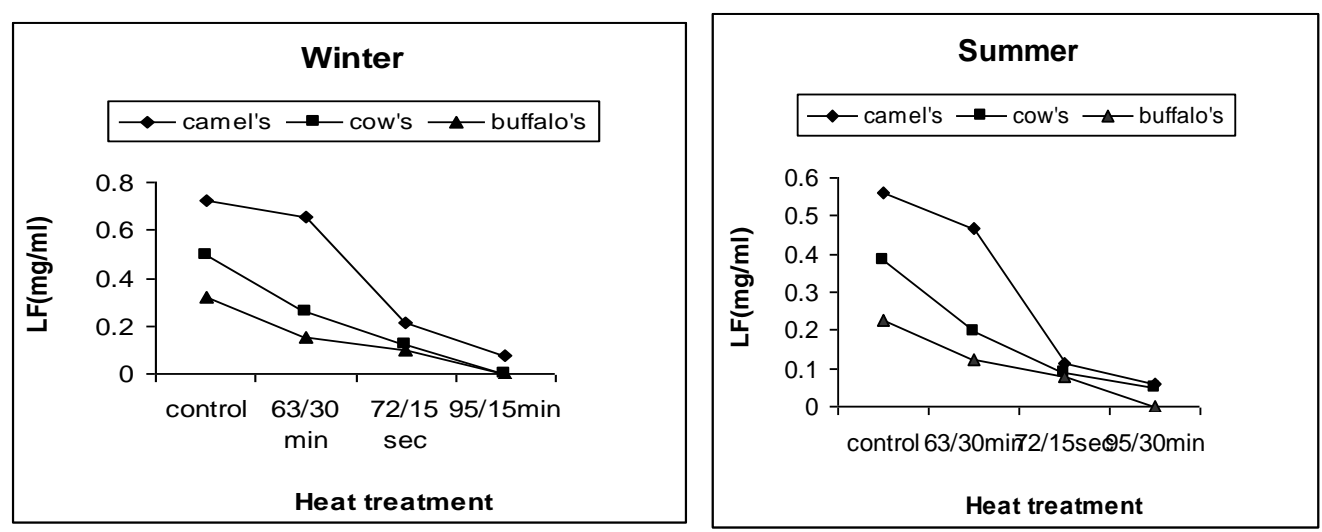

Fig. 2. Effect of heat treatment and season on camel's, cow's and buffalo's milk lactoferrin.
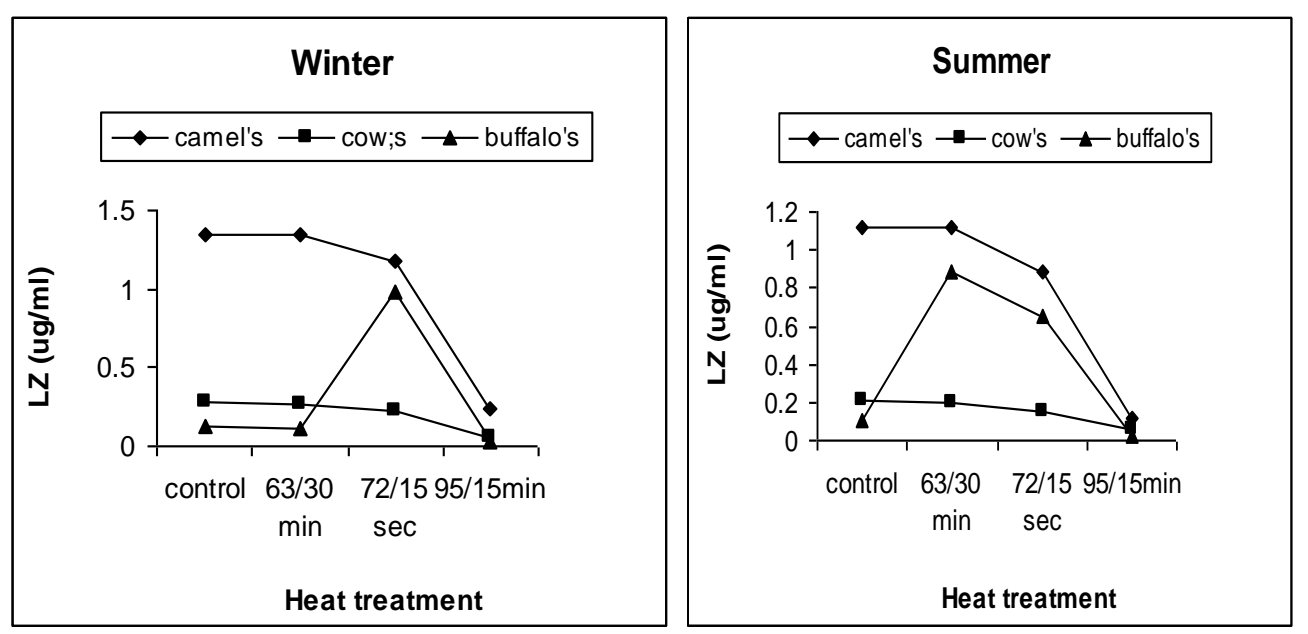

Fig. 3. Effect of heat treatment and season on camel's, cow's and buffalo's milk lysozyme. 
Significant differences were observed in lysozyme (LZ) from three kinds of milk. Camel's milk contained $1.12 \pm 0.14 \mathrm{ug} / \mathrm{ml}$ and $1.35 \pm 0.21 \mathrm{ug} / \mathrm{ml}$ in summer and winter respectively. Cow's milk $0.21 \pm 0.14$ and $0.27 \pm 0.17$, buffalo's milk $0.10 \pm 0.11$ and $0.12 \pm 0.18$ in summer and winter respectively (Table 3). Fig. 3 showed the effect of various heat treatment on lysozyme in camel's, cow's and buffalo's milk. Heating milk at 63 and $72^{\circ} \mathrm{C}$ for $30 \mathrm{~min}$. and $15 \mathrm{sec}$. respectively had significant effect on lysozyme in the three kinds of milk (Table 3). However, highly significant differences between the effect of $72^{\circ} \mathrm{C}$ and $95^{\circ} \mathrm{C}$ were observed especially in camel's and cow's milk. Increasing the temperature to $95^{\circ} \mathrm{C}$ for 15 min resulted in a significant greater loss of lysozyme in milk. Buffalo's milk lysozyme was more affected by heat treatment than camel's and cow's milk /ysozyme. Although at $95^{\circ} \mathrm{C} / 30 \mathrm{~min}$. , the entire activity of buffalo's and cow's milk lysozyme was lost versus $94 \%$ of activity loss of camel's milk lysozyme, there was significant differences among them. Different results were given by some other authors, they mentioned, that only $75 \%$ of lysozyme maintains after milk pasteurization at $80^{\circ} \mathrm{C} 15 \mathrm{~s}$ (Farkey, 2002). In current research lysozyme showed higher results and was more stable during heat treatment. On the other hand, season of the year affected the quantity of lysozyme since the highest quantity was recorded in raw camel's milk $(1.35 \pm 0.21 \mathrm{ug} / \mathrm{ml})$ in winter season, but the lowest one was recorded in raw buffalo's milk in winter season $(0.12 \pm 0.18 \mathrm{ug} / \mathrm{ml})$ compared to summer season.

Table 3. Effect of heat treatments and seasons of the year on the quantity of lysozyme (ug $/ \mathrm{ml}$ ) in camel's, cow's and buffalo's milk (Average $\pm \mathrm{SE}$ of three replicates).

\begin{tabular}{|c|c|c|c|c|c|c|}
\hline \multirow{2}{*}{ Treatments } & \multicolumn{3}{|c|}{ Summer } & \multicolumn{3}{c|}{ Winter } \\
\cline { 2 - 7 } & Camel's & Cow's & Buffalo's & Camel's & Cow's & Buffalo's \\
& milk & milk & milk & milk & milk & milk \\
\hline Control & $1.12 \pm 0.14^{\mathrm{a}}$ & $0.21 \pm 0.21^{\mathrm{a}}$ & $0.10 \pm 0.11^{\mathrm{a}}$ & $1.35 \pm 0.21^{\mathrm{a}}$ & $0.27 \pm 0.17^{\mathrm{a}}$ & $0.12 \pm 0.18^{\mathrm{a}}$ \\
\hline $63^{\circ} \mathrm{C} / 30 \mathrm{~min}$. & $1.12 \pm 0.21^{\mathrm{b}}$ & $0.19 \pm 0.15^{\mathrm{b}}$ & $0.89 \pm 0.21^{\mathrm{b}}$ & $1.35 \pm 0.13^{\mathrm{b}}$ & $0.26 \pm 0.18^{\mathrm{b}}$ & $0.11 \pm 0.16^{\mathrm{b}}$ \\
\hline $72^{\circ} \mathrm{C} / 15 \mathrm{Sec}$. & $0.89 \pm 0.16^{\mathrm{c}}$ & $0.14 \pm 0.18^{\mathrm{c}}$ & $0.65 \pm 0.13^{\mathrm{c}}$ & $1.18 \pm 0.16^{\mathrm{c}}$ & $0.22 \pm 0.15^{\mathrm{c}}$ & $0.98 \pm 0.14^{\mathrm{c}}$ \\
\hline $95^{\circ} \mathrm{C} / 15 \mathrm{~min}$. & $0.12 \pm 0.18^{\mathrm{d}}$ & $0.06 \pm 0.17^{\mathrm{d}}$ & $0.02 \pm 0.14^{\mathrm{d}}$ & $0.23 \pm 0.19^{\mathrm{d}}$ & $0.05 \pm 0.12^{\mathrm{d}}$ & $0.03 \pm 0.11^{\mathrm{d}}$ \\
\hline
\end{tabular}

Means \pm standard error

$a, b, c$ Means within the same column with different letters are significantly different $(P<0.05)$. 


\section{CONCLUSION}

From the results obtained it can be concluded that (a) Camel's milk was more heat stable than cow's and buffalo's milk. (b) Antimicrobial factors are significantly present in higher concentration in camel milk than in cow's or buffalo's milk and they are more heat resistant than their counterparts in cow's and buffalo's milk. This means that the biological activity of protective proteins in heat-treated camel milk at $95^{\circ} \mathrm{C} / 30 \mathrm{~min}$. was higher than that of cow's and buffalo's milk proteins.(c) On the other hand, the quantity of antimicrobial factors were significantly present in higher concentration in winter milk compared to summer milk.

\section{REFERENCES}

1. Benkerroum, N. 2008. Antimicrobial activity of lysozyme with special relevance to milk. African J. Biotechnol. 7 : 4856-4867.

2. Chen, C.-C.; Tu, Y.-Y. and Chang, H.-M. 2000.Thermal stability of bovine milk immunoglobulin $\mathrm{G}(\mathrm{IgG})$ and the effect of added thermal protectants on the stability. J. Food Sci., 65 : 188-193.

3. Dhar, J., Fichtali, J.; Skura, B. J.; Nakai, S. and Davidson, A. G. F. 1996. Pasteurization of an HTST system for human milk. J. Food Sci, 61: 569-572.

4. Dominguez, E.; Perez, M. D.; Puyol, P.; Sanchez, L. and Calvo, M. 2001. Effect of $\mathrm{pH}$ on antigen-binding activity of IgG from bovine colostrum upon heating,. $J$. Dairy Res., 68 : 511-518.

5. Elfstrand, L.; Lindmark-Mansson, H.; Paulsson, M.; Nyberg, L. and Akesson, B. 2002. Immunoglobulins, growth factors and grows hormone in bovine colostrum and the effects of processing,. Int. Dairy J. $12: 879-887$.

6. Farkey, N. Y. 2002. Other Enzymes,. in Encyclopedia of Dairy Sciences, H. Roginski, J. W. Fuquay, P. F. Fox Ed. Amsterdam: Academic Press, 3 : 946-947.

7. Gorbenko, G. P.;. loffe Kinnunen, V. M. and Paavo, K. J. 2007. Binding of Lysozyme to phospholipid bilayers: Evidence for protein aggregation upon membrane association,. Biophys. J., $93: 140-153$.

8. Gray, G. D., Nickelson, M. M., and Crim, J. A. 1969. The demonstration of two gamma-globulin subclasses in the goat. Immu- nochemistry, 6: 641-644.

9. Król, J.; Brodziak, A.; Litwińczuk, Z.and Szwajkowska, M. 2011. Whey proteins use in health promotion. Żywienie Człowieka i Metabolizm, Vol. XXXVIII, No. 1, pp. 36-45. 
10. Li-Chan, E., Kummer, A., Losso, J. N., Kitts, D. D., and Nakai, S. 1995. Stability of bovine immunoglobulins to thermal treatment and processing. Food Res. Int, 28: 9-16.

11. Luf, W., and Rosner, E. 1997. Thermal stability of lactoferrin in bovine milk. Wiener Tieraeztliche Monatsschrift, 84: 70-73.

12. Maynard, F.; Pierre, A. and Maubois, J. L. 1989. Fractionation of human lactoferrin and alpha-lactalbumin using microfiltration and ultrafiltration membranes. Lait 69:59-69.

13. Mehra, R.; Marnila, P. and Korhonen, H. 2006. Milk immunoglobulins for health promotion, Int. Dairy J. 16 : 1262-1271.

14. Mix, E.; Goertsches, R. and Zettl, U. K. 2006. Immunoglobulins-basic considerations, J. Neurol., 253 :V9-V17.

15. Priyadarshini, S. and Kansal, V. K. 2003. Biochemical characterization ofbuffalo (Bubalus bubalis) milk lysozyme, J. Dairy Res. 70 : 467-472.

16. Samaranayake, Y. H.; Samaranayake, L. P.; Pow, E. H. N.; Beena, V. T. and Yeung, K. W. S. 2001. Antifungal effects of lysozyme and lactoferrin against genetically similar, sequential candida albicans isolates from a human immunodeficiency virus-infected southern chinese cohort. J. Clin Microbiol., 39: 3296-3302.

17. SPSS. 1998. Statistical Package for Social Scince.SPSS Inc.Chicago, Illions, USA.

18. Turner, S.A.; Williamson, J.H.; Roche, J.R.and Kolver, E.S. 2003. Diet and genotype affect milk lactoferrin concentrations in late lactation. Proceedings of the New Zealand Society of Animal Production Vol. 63, pp. 87-90.

19. Vetter A.; Argüello A.; Baumrucker C. and Bruckmaier R.M. 2013. Short communication: Fractional milking distribution of immunoglobulin $\mathrm{G}$ and other constituents in colostrum. J. Dairy Sci., 96:5919-5922.

20. Walter, L. H. and Theil, P. K. 2011. Perspectives on immunoglobulins in colostrum and milk. Nutrients $3: 442-474$. 


\title{
تأثير المعاملات الحرارية المختلفة و فصول السنه على البروتينات المناعيه فى انواع الألبان المختلفة
}

\author{
حامد السيد حاتم \\ بحوث كيمياء الالبان - دعهُ بحوث الانتاج الحيوانى - مركز البحوث الزراعية
}

تهدف هذه الدراسـه الـى تقيم الثبـات الحـرارى و فصـول السـنه للبروتينـات المناعيـه مثنل

الامينوجلوبيولين و اللاكتوفيرين و الليزوزيم للبن الابل والابقار و الجاموس. حيث تم اخذ عينات اللبن

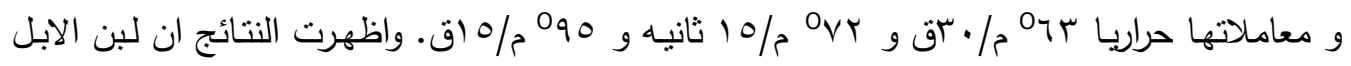

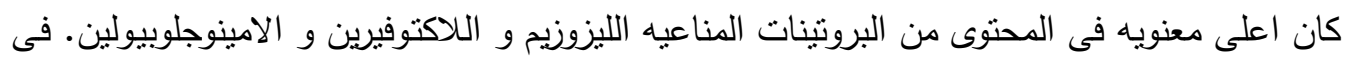

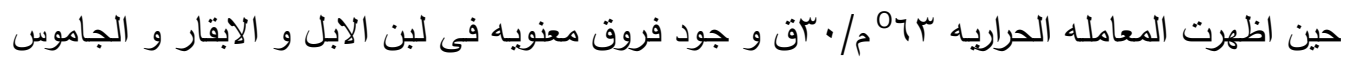
للامينوجلوبيولين. و كان الفقد فى كميه الامينوجلوبيولين اعلى للابقار ثم الجاموس مقارنتا بلبن الابل هوديل

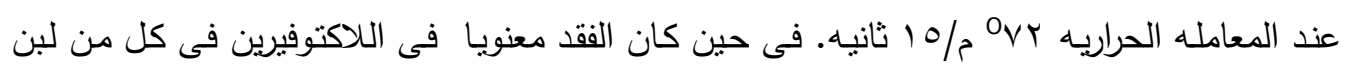

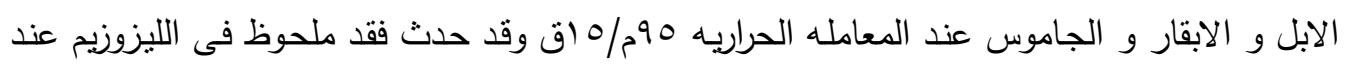

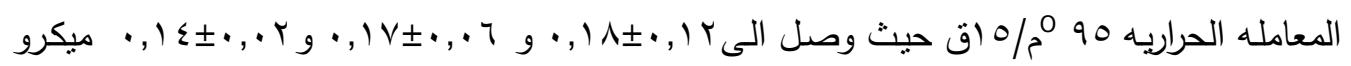

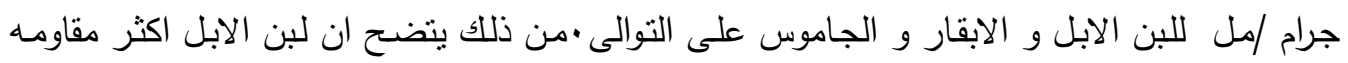

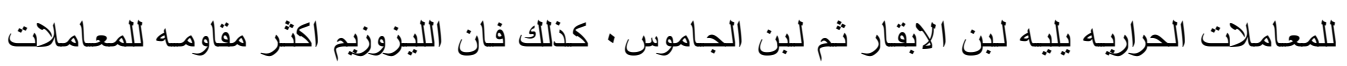

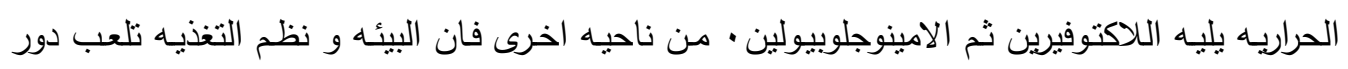

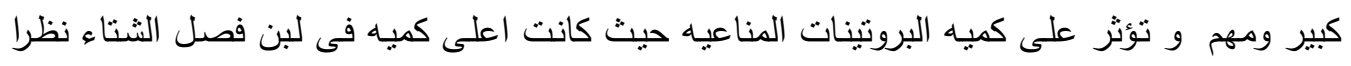
لتوافر البيئه المناسبه و التغذيه والرعى مقارنه بلبن الصيف حيث التئ التغيه الجافه. 